\title{
Analisis Pertarungan Wacana Video Pendek Covid-19 di Media Sosial
}

\author{
I Komang Arba Wirawan', Dewa Made Darmawan², I Wayan Mudra ${ }^{3}$ \\ ${ }^{1,2}$ Prodi Produksi Film dan Televisi, ${ }^{3}$ Prodi Kriya Seni, Fakultas Seni Rupa dan Desain, \\ Institut Seni Indonesia Denpasar. \\ 'arbawirawan@isi-dps.ac.id
}

\begin{abstract}
Kecepatan teknologi digital berdampak terhadap produksi film atau video pendek, pola distribusi, dan konsumsi yang sangat cepat pada era Covid-19 ini. Kehadiran video pendek Covid-19 di Indonesia sangat variatif, kreatif dan inovatif membawa pertarungan wacana di kalangan masyarakat. Penelitian ini bertujuan untuk menganalisis pertarungan wacana video pendek Covid-19 di media social khususnya WhatsApp (WA), mulai 13 April s/d 5 Agustus 2020. Penelitian ini menggunakan pendekatan diskriptif kualittatif didukung data kuantitatif, dan teknik pengumpulan data dilakukan dengan observasi, dokumentasi, dan penyebaran kuesioner secara on line. Sumber data utama penelitian ini adalah delapan video pendek terpilih mengenai kampanye Covid-19 yang pernah beredar di media sosial WA berbahasa Indonesia. Teori yang dipergunakan adalah teori wacana, (Stuart Hall) dan estetika (Virilio). Kedua teori ini diaplikasikan secara eklektik untuk menganalisis secara kritis proses konsumsi video pendek Covid-19 oleh masyarakat. Hasil penelitian menunjukkan bahwa video pendek kampanye Covid-19 yang beredar di media WhatsApp ada dua model yang melakukan pertarungan wacana bertujuan untuk kepentingan politik. Kelompok video pertama mengandung muatan hoax bertujuan untuk menimbulkan kepanikan di masyarakat, dan kelompok video kedua bertujuan membangun kesadaran masyarakat dalam menghadapi Covid-19. Video yang kedua ini adalah video yang mendukung kampanye pemerintah, sebagai wacana tanding menenangkan wacana video pendek kampanye Covid-19. Pada kedua jenis video ini tergambar pertarungan wacana ideologi, politik dan ekonomi dalam memenangkan dan memengaruhi masyarakat melalui media social. Kesimpulannya video pendek Covid-19 yang beredar di media sosial wacana pertarungannya didasari atas berbagai kepentingan, dan tidak sematamata hanya bertujuan baik.
\end{abstract}

Kata kunci: analisis, pertarungan, video pendek, covid-19, media sosial.

This study aims to analyze the battle between the short video discourse of Covid-19 on social media, especially WhatsApp (WA), from April 13 to August 5 2020. The presence of discourse is due to the speed of digital technology, which not only helps the pattern of production of short films or videos but also patterns. distribution and consumption. This consumption pattern brings about a short video discourse battle with the theme Covid-19, very pariative, creative and innovative during the Covid-19 pandemic in Indonesia. Short video themes come in a variety of styles. However, of the many short videos produced, distributed and consumed, they contain content that contains discourse battles. The short video is continuously consumed by the public without going through a process of checking and checking the correctness of the source and content or short video content. One group of creative video production based on facts, the other group spreading Hoax or Buser. The fight continues to exploit the discourse of fear of Covid-19. The Covid-19 discourse on social media is interesting to research to find out the subjective agenda behind the production of the short Covid-19 video. The main data of this research are eight short videos selected about the Covid-19 campaign in the form of documentation that has been broadcast on WA social media in Indonesian. The theories used are discourse theory, (Stuart Hall) and aesthetics. Both of these theories are applied eclectically to critically analyze the process of consuming the Covid-19 short video by the public. The results of the analysis show that the short video of the Covid-19 campaign is managed with a clear discourse agenda for political purposes that aims to create panic in the community. At the same time, there is a discourse that supports the government's campaign on social media WA, as a discourse to calm people's awareness in facing Covid-19. The short video discourse of the Covid-19 campaign shows how discourse battles that contain ideology, politics and economy compete to win in influencing society through social media.

Keywords: analysis, short videos, covid -19 social media. 


\section{PENDAHULUAN}

Kemajuan teknologi digital membuat percepatan dalam pola produksi, distribusi dan konsumsi video dan film di media social (medsos). Dunia komunikasi dan informasi dipenuhi oleh medsos, dari ruang public sampai ruang privat sekalipun. Informasi sampai pada smartphone di tangan konsumsi masyarakat. Informasi dan komunikasi memiliki pola yang sangat cepat menyebar dan dapat menjadi viral dalam hitungan detik. Informasi video pendek begitu cepat di copy-pasta, terkadang tanpa dibaca secara lengkap apalagi, dianalisis kebenarannya. juga Pertarungan wacana video pendek tema Covid-19 tersebar begitu massif semenjak ditemukannya virus ini pada 31 Desember 2019, WHO China Country Office melaporkan kasus pneumonia yang tidak diketahui etimologinya di Kota Wuhan, Provinsi Hubei, Cina. Pada tanggal 7 Januari 2020, Cina mengindentifikasi pneumonia yang tidak diketahui etimologinya tersebut sebagai jenis baru coronavirus (coronavirus disease, COVID-19). Pada tanggal 30 Januari 2020 WHO telah menetapkan sebagai kedaruratan kesehatan masyarakat yang meresahkan dunia/Public Health Emergency of International concern (KKMMD/ PHEIC). Penambahan kasus Covid-19 berlangsung cepat dan sudah terjadi penyebaran antar negara (Pedoman Pencegahan dan Pengendalian coronavirus desease atau covid-19, Dirjen P2, 2020:11).

Pemerintah Indonesia melakukan kampanye \#dirumahaja, \#kerjadirumah, dan \#beribadahdirumah serta kampanye cuci tangan, jaga jarak, jaga kesehatan. Kampanye tersebut melalui media social, media mainstream televisi nasional dan radio. Kampanye yang tidak kalah masifnya adalah melalui media social. Media social seperti FB dan WA group menjadi media yang cepat untuk menjadi viral sebuah video pendek dengan berbagai tema yang diusung. Tema-tema yang terkait dengan COVID-19, video pendek wacana rekomendasi standar untuk mencegah penyebaran infeksi melalui cuci tangan secara teratur menggunakan sabun dan air bersih, menerapkan etika batuk dan bersin, menghindari kontak secara langsung dengan ternak dan hewan liar serta menghindari kontak dekat dengan siapapun yang menunjukkan gejala penyakit pernapasan seperti batuk dan bersin.

Dilain pihak berbagai tema kampanye video pendek yang tersebar melalui FB dan WA tema yang memiliki konten hoaks (tidak benar) dan cenderung membuat resah kabar hoaks tersebut dapat menimbulkan kepanikan di masyarakat. Konten tersebut seperti pada web covid19. go.id, menemukan 199 berita salah atau hoak di laman covid19.go.id (13 April-5 Agustus 2020) hoaks terkait dengan wabah virus corona. Sedangkan Kementrian Komunikasi dan Informatika (Kemenkominfo) sampai senin, 16 Maret 2020 sudah menemukan 232konten hoaks dan diinformasi terkait virus corona atau COVID-19, (https://www.covid19.go.id). Penelitian analisis pertarungan wacana video pendek di media social WA belum banyak dilakukan. Terkait pandemi COVID-19 yang menyerang keseluruh dunia tersaji banyak informasi dimedia sosial. Berbagai informasi berupa video pendek dengan konten yang mengandung hoaks (kebohongan). Konten hoaks tersebut di lawan dengan wacana tanding berita-berita dari pemerintah dan masyarakat. Untuk memperkaya penelitian ini dilakukan state of the art yang berfungsi untuk analisis dan memperkaya pembahasan penelitian, serta membedakannya dengan penelitian yang sedang dilakukan. Dalam penelitian ini disertakan beberapa jurnal penelitian sebelumnya yang berhubungan dengan konsep analisis pertarungan wacana, seperti penjelasan berikut ini.

Sarmita (2019), Penelitian dengan judul Wacana KB Krama Bali: Analisis Persepsi Warganet di Media Sosial Facebook diambil dari Journal of Bali Studies. Artikel ini membahas persepsi warganet terkait wacana KB Krama Bali pada media sosial facebook. Metode kualitatif dengan hasil variasi pemberitaan wacana KB Krama Bali di media social facebook oleh beberapa media masa online, dilihat dari judul dan intensitas pemberitaannya. Bervariasinya pemberitaan wacana ini tidak terlepas dari kebijakan internal dan pengaruh eksternal media. Penelitian Sarmita sama-sama meneliti dimedia sosial FB. Tetapi hanya meneliti persepsi warganet, penelitian penulis meneliti wacana video pendek COVID-19 pandemi yang sedang berlangsung.

Fatmawati dkk, (2019) penelitian dengan judul Analisis Berita Hoaks di Korpus Sosial Media Guna Mengembangkan Model "Kapak Hoaks" (Kemandirian Pembaca Menganalisis Konten Hoaks) Studi Analisis Wacana Kritis di Jurnal LiTe. Artikel ini membahas berkembangnya hoaks di media sosial yang dapat menyebabkan perpecahan dan pertikaian di tengah masyarakat. Hal paling utama yang dapat dilakukan adalah dengan melakukan dorongan terhadap peningkatan kemandirian pembaca dalam menganalisis sebuah konten, terutama konten hoaks.

Jenis media sosial yang paling banyak digunakan sebagai wadah penyebaran berita hoaks adalah jejaring sosial (facebook, instagram, WhatsApp). Ciri lain yang ada dalam berita hoaks yang dapat masyarakat kenali yaitu berita hoaks tertulis dalam huruf kapital yang tidak tepat, tidak memiliki narasumber yang jelas, tidak memiliki wartawan yang jelas, penulis tidak melihat konteks, tidak ada gambar pendukung berita, antara berita dan gambar pendukung tidak berhubungan, dan waktu dan tempat kejadian tidak jelas. Persamaan penelitian ini dengan penulis sama-sama meneliti jejaring sosial FB dan WA, dan mengenali berita hoaks. Perbedannya dengan penulis objek yang dianalisis beritanya namun penulis khusus wacana video pendek bertema Covid-19. 
Annistri1\& Sugandi, (2017) penelitian dengan judul "Analisis Wacana Kritis Sara Mills dalam Video Klip Musik Despacito Karya Luis Fonsi". Penelitian ini membahas video klip musik Despacito karya Luis Fonsi. Video klip musik Despacito pernah menuai kontra akibat lirik lagunya yang mengajak perempuan untuk bercinta. Metode penelitian kualitatif dan menggunakan paradigma kritis. Analisis wacana kritis Sara Mills yang menggunakan analisis posisi subjek-objek dan analisis posisi pembaca/penonton. Hasil penelitian menunjukkan bahwa perempuan dan tubuhnya yang ditampilkan dalam video klip merupakan objek jual untuk meningkatkan kepopuleran melalui bentuk visualisasi dan audio pada video klip tersebut. Penelitian ini sama-sama meneliti video namun berbeda genre, penulis video pendek Covid-19, penelitian ini video klip music.

Prawitasari, (2014) A Critical Discourse Analysis of Three (3) Advetisement Entitled "Always on, Bebas Itu nyata" Girl's Version. Penelitian ini membahas kekuatan ujaranujaran dalam narasi iklan Three (3) yang berjudul "Always on, Bebas itu Nyata' dengan pendekatan kualitatif dengan Analisa dokumen. Teori yang dipergunakan CDA sebagai analisis kritis. Penelitian ini sama-sama mempergunakan teori CDA namun objek penelitian yang berbeda.

Coronavirus adalah keluarga besar virus yang menyebabkan penyakit mulai dari gejala ringan sampai berat. Ada setidaknya dua jenis virus corona yang diketahui menyebabkan penyakit yang dapat menimbulkan gejala berat seperti Middle East Respiratory Syndrome (MERS) dan Severe Acute Respiratory Syndrome (SARS). Coronavirus Disease 2019 (COVID-19) adalah penyakit jenis baru yang belum pernah diidentifikasi sebelumnya pada manusia. Virus penyebab COVID-19 ini dinamakan Sars-CoV-2. Virus corona adalah zoonosis (ditularkan antara hewan dan manusia). Penelitian menyebutkan bahwa SARS ditransmisikan dari kucing luwak (civet cats) ke manusia dan MERS dari unta ke manusia. Adapun, hewan yang menjadi sumber penularan COVID-19 ini masih belum diketahui.

Tanda dan gejala umum infeksi COVID-19 antara lain gejala gangguan pernapasan akut seperti demam, batuk dan sesak napas. Masa inkubasi rata-rata 5-6 hari dengan masa inkubasi terpanjang 14 hari. Pada kasus COVID-19 yang berat dapat menyebabkan pneumonia, sindrom pernapasan akut, gagal ginjal, dan bahkan kematian. Tanda-tanda dan gejala klinis yang dilaporkan pada sebagian besar kasus adalah demam, dengan beberapa kasus mengalami kesulitan bernapas, dan hasil rontgen menunjukkan infiltrat pneumonia luas di kedua paru.

Pada 31 Desember 2019, WHO China Country Office melaporkan kasus pneumonia yang tidak diketahui etiologinya di Kota Wuhan, Provinsi Hubei, Cina. Pada tanggal 7 Januari 2020, Cina mengidentifikasi pneumonia yang tidak diketahui etiologinya tersebut sebagai jenis baru coronavirus (coronavirus disease, COVID-19). Pada tanggal 30 Januari 2020 WHO telah menetapkan sebagai Kedaruratan Kesehatan Masyarakat Yang Meresahkan Dunia/ Public Health Emergency of International Concern (KKMMD/PHEIC). Penambahan jumlah kasus COVID-19 berlangsung cukup cepat dan sudah terjadi penyebaran antar negara, (Aziza, 2020:11).

Sampai dengan tanggal 25 Maret 2020, dilaporkan total kasus konfirmasi 414.179 dengan 18.440 kematian (CFR 4,4\%) dimana kasus dilaporkan di 192 negara/wilayah. Diantara kasus tersebut, sudah ada beberapa petugas kesehatan yang dilaporkan terinfeksi. Pada tanggal 2 Maret 2020, Indonesia melaporkan kasus konfirmasi COVID-19 sebanyak 2 kasus. Sampai dengan tanggal 26 April 2020, Indonesia melaporkan 8.882 konfirmasi COVID-19, 1.107 sembuh, dan 743 meninggal dunia (covid19.go.id). Penelitian tentang wacana video pendek khususnya di media sosial, belum banyak dilakukan para ahli. Di antara yang sedikit itu, terdapat fokus penelitian pada wacana video pendek COVID-19 di media sosial, karena fenomena ini baru dan sedang berlangsung sehingga dapat dikatakan penelitian ini penting.

Analisis wacana juga untuk membongkar kuasa yang ada dalam setiap proses bahasa: batasan-batasan apa yang diperkenankan menjadi wacana, perspektif yang mesti dipakai, dan topik apa yang dibicarakan. Dengan pandangan semacam ini wacana melihat bahasa selalu terlibat dalam hubungan kekuasaan, terutama dalam pembentukan subjek, dan berbagai tindakan representasi yang terdapat dalam masyarakat (Eriyanto, 2005: 6). Analisis wacana kritis (Critical Discourse Analysis/CDA), wacana di sini tidak dipahami semata sebagai studi bahasa. CDA dipergunakan untuk membedah wacana video pendek COVID-19 untuk memberikan analisis yang ilmiah.

Media sosial (medsos) telah memperkenalkan komunikasi baru praktik, peyediaan pola interaksi yang baru, menciptakan bentuk ekspresi baru, merangsang luas partisipasi masyarakat, dan sebagainya. Medsos berkembang pesat dan signifikan dalam proses sosial dan politik. Medsos telah memperkenalkan pola komunikasi baru, menciptakan bentuk ekspresi baru, merangsang partisipasi sipil yang luas, dan sebagainya. Medsos adalah media digital baru untuk interaksi sosial. Konsep ini mengacu pada satu set aplikasi berbasis internet yang dibangun berdasar teknologi Web 2.0 dan yang memungkinkan konten yang dibuat pengguna dapat dibuat dan dipertukarkan (Kaplan \& Haenlein 2010 dalam Bardici, 2012:1). Ada berbagai bentuk medsos, seperti situs jaringan (FB, WA, youtube, dll), Media ini untuk interaksi social memfasilitasi proses keterlibatan sipil, memicu mobilisasi publik, mengaktifkan jurnalisme warga untuk mendapatkan dukungan dari komunitas global (Khamis 
\& Vaughn 2011; Khamis 2011; Eltanatawy \& Wiest 2011 dalam Bardici, 2012:2). (281).

Video adalah gambar bergerak, bercerita terdiri dari audio-visual, yang memiliki kekuatan yang tidak dapat disangkal. Video juga menawarkan cara menarik bagi orang dan masyarakat untuk berpromosi, melucu, mendidik, menginspirasi, mengejutkan, memotivasi, hingga menghangatkan hati. Video bersifat pribadi, menarik perhatian, dan beresonansi dengan pemirsa dengan cara yang tidak bisa dilakukan media lain (Walter, 2014:34). Video juga salah satu media yang fleksibel dapat secara mendalam menceritakan kisah atau imajinasi (Walter,2014:73). Video adalah konten yang paling banyak diposting di FB dan WA.

Berdasarkan latar belakang tersebut maka permasalahan yang akan diteliti pada usulan ini adalah bagaimana analisis video pendek COVID-19 di media social WA berbahasa Indonesia. Penelitian ini dirancang satu tahun dengan tujuan khusus yang ingin dicapai adalah menganalisis pertarungan wacana tujuan diproduksi, didistribusi, dan konsumsi video pendek COVID-19 di masyarakat. Urgensi penelitian ini adalah untuk menyadarkan masyarakat untuk menyaring informasi video pendek COVID-19 di WA, sebagai kekuatan bersama melawan virus corona. Untuk tidak mempercayai berita tidak benar hoaks terkait dengan COVID-19, agar tidak menambah beban psikologis dan menurunkan imunitas tubuh masyarakat.

\section{METODE PENELITIAN}

Komponen penting dalam melakukan penelitian adalah penerapan metodologi yang tepat sehingga memudahkan tim peneliti dalam melakukan proses pengumpulan data, menganlisis dan menyajikan hasil analisis data. Adapun metode digunakan dalam penelitian ini adalah metode diskriptif kualitatif untuk melakukan analisis kritis terhadap wacana video pendek COVID-19. Penelitian kualitatif yaitu penelitian inkuiri naturalistik atau alamiah, etnografi, interaksionis simbolik, perspektif ke dalam, etnometodelogi, fenomenologis, studi kasus, interpretatif, ekologis, dan deskriptif (Moleong, 2017:2). Sumber data utama penelitian ini adalah dipilih 8 video pendek Covid-19 berbahasa Indonesia yang dimuat pada WA, mulai dari tanggal 13 April s/d 24 April 2020. Metode pengumpulan data dilakukan dengan observasi, wawancara, dan penyebaran kuesioner secara on line, dan penentuan responden sebagai sumber data dilakukan secara non probality. Secara teoretis penelitian ini akan dikaji menggunakan teori wacana, dan estetika dan diterapkan secara ekletik.

Jumlah responden yang yang dikirimkan sampel video untuk diberi tanggapan sebanyak dua puluh. Kedua puluh responden ini didapatkan berdasarkan rekaman jawaban kuisener pada google form, sedangkan kuisener yang disebarkan sebanyak 157 kuisener. Ke 157 tersebut terdiri dari WA group PROSFISI (Perkumpulan Program Studi Film dan Televisi), pengurus PROSFISI, dosen Prodi Film dan Televisi, dan mahasiswa Film dan Televisi.

Penelitian ini dirancang dan dilaksanakan secara sistematik melalui tahapan-tahapan sebagai berikut: (1) melakukan seleksi data video covid-19, (2) penentuan responden dipilih berdasarkan kompetensi keahlian video dan film analisis, (3) pengiriman kuisener melalui google form, (4) pengumpulan, pengolahan data, tabulasi data, dan (5) analisis data dan penyimpulan. Variabel penelitian ini adalah indeks pertarungan wacana video pendek Covid-19. Operasiaonal variabel yang dimaksud indeks pertarungan wacana adalah perhitungan indeks yang diperoleh dari jawaban responden.

\section{PEMBAHASAN}

\section{Pertarungan wacana Video pendek Covid-19}

Perbedaan antara "produksi video" dan "produksi televisi" menjadi semakin kabur. Sebagian produksi video berkaitan dengan pembuatan program non-siaran. Produksi video umumnya didistribusikan melalui DVD atau online media sosial WA. Meski produksi video umumnya dibuat dengan budget lebih rendah, dan alat smart phone bukan berarti hanya sedikit orang yang melihat produksi video tersebut. Video tersebut adalah sebuah berita atau narasi yang dapat memengaruhi penonton atau masyarakat. Hal ini berarti bahwa video pendek Covid-19 memenuhi syarat sebagai suatu narasi proses konstruksi realitas. Konstruksi realitas tersebut dikonsumsi berdasarkan kepentingan politik, ideologi dan ekonomi yang menyertainya. Pertarungan wacana video pendek Covid-19 dibedah dengan teori wacana Stuart Hall.

Berkaitan dengan sistem pilihan utama dari bahasa yang digunakan untuk membangun representasi realitas yang diseleksi, menurut pendapat Chouliaraki (dalam Barker \& Galasinski, 2001: 65) berikut dapat dirujuk:

"Discourse is closely related to the assumption that discourse is a system of options from which language users make their 'choices'. The construction of any representation of 'reality' is necessarily selective, entailing decisions as to which aspects of that reality to include and how to arrange them".

"Diskursus adalah sebuah sistem opsi dari mana pemakaipemakai bahasa membuat 'pilihan-pilihan'. Konstruksi dari setiap representasi atau 'realitas' bersifat selektif, meliputi keputusan terhadap aspek-aspek realitas yang mana yang masuk dan bagaimana mengaturnya".

Batasan diskursus yang disampaikan Chouliaraki di atas dengan jelas menggarisbawahi wacana sebagai sistem 
konstruksi, dibuat oleh pihak yang berkepentingan dengan menonjolkan hal-hal yang sesuai dengan tujuannya. Proses produksi video Covid-19 di bawah ini terdapat 8 video terpilih menonjolkan sesuai kepentingan masing-masing konstruksi realitas bersifat selekstif mengatur visual yang muncul video sebagai berikut;

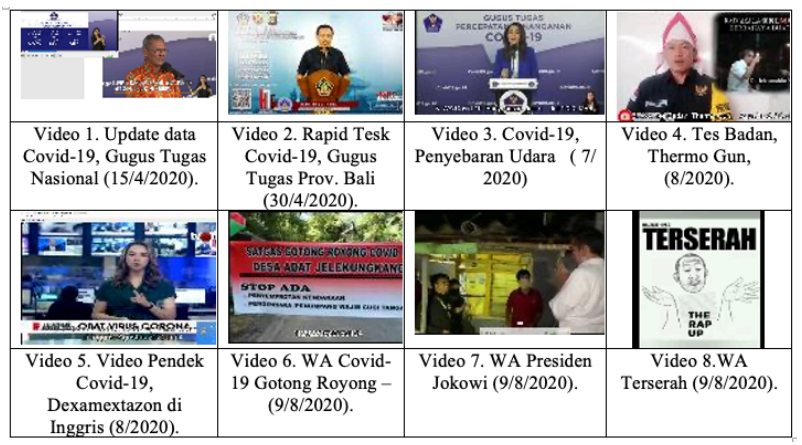

Gambar 1. Data 9 video Covid-19 terpilih 2020.

(Sumber. Media sosial whats App/WA)

Video di atas juga dibedah dengan teori estetika, untuk melihat lebih jauh lagi, bahwa trik-trik tertentu dalam produksi (film dan video) telah memampukan manusia masa kini hidup di dalam dua dunia. Sebagaimana yang dituliskan dalam bukunya The Aesthetics of Disappearance, "...trik, yang secara cerdik diterapkan, kini memampukan kita membuat yang supernatural, khayali bahkan yang tidak mungkin menjadi tampak...” (Virilio, 1991: 15). Pada video delapan objek penelitian terpilih diterapkan yang tidak tampak menjadi tampak teknologi editing memungkinkan hal ini.

Visual yang ditayangkan pada video pendek tema Covid-19 dapat di analisis seperti table 1. di bawah ini.

Tabel 1. Indeks Pertarungan Video Covid-19 Sumber. Arba 2020

\section{INDEKS PERTARUNGAN VIDEO COVID-19}

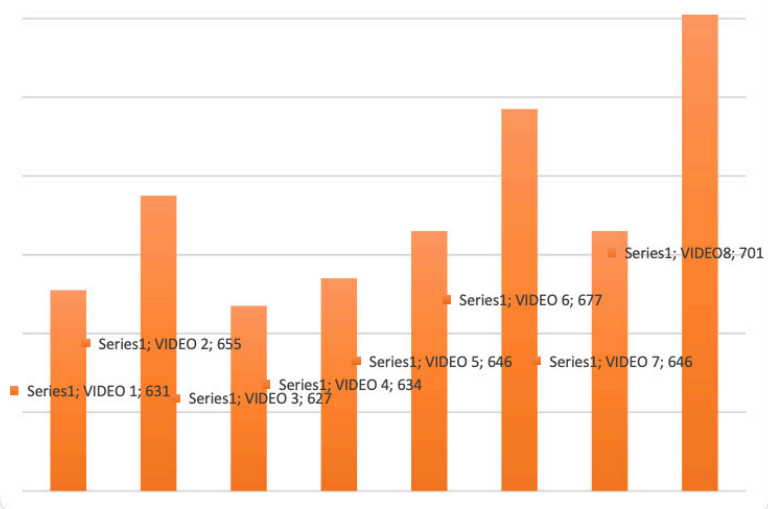

Analisis video pertama dengan judul Update data Covid-19, Gugus Tugas Nasional (15/4/2020), memperoleh indeks 631, video ini mendapatkan indeks berdasarkan fakta tertinggi yaitu 83 , namun indeks estetik hanya 51. Berdasarkan analisis teori wacana video ini tidak mengandung unsur hoax atau tidak benar. Unsur estetik menjadi rendah penilaian responden dapat dikatakan video ini kurang memenuhi nilai estetik namun memiliki aspirasi informasi yang tinggi 81. Berikutnya analisis pada video kedua, dengan nilai indeks 655 (rangking 3). Nilai fakta tertinggi 81dan aspirasi informasi yang tidak mengadung hoax. Ketiga video ini nilai indeks pertarungan wacana terendah 627, ini menunjukkan estetik yang kurang memiliki alur cerita, walaupun tidak terdapat unsur hoax. Keempat, video ini memiliki fakta 70 persepsi responden yang sama, ini mengindikasikan pertarungan wacana di masyarakat memiliki kekuatan yang sama antara hoax dengan anti hoax dengan opini pribadi tertinggi 70 dan estetik terendah 49, mengindikasikan kurangnya alur cerita yang mendukung video ini.

Kelima, video ini memiliki fakta tertinggi 74 mengindikasikan dengan alur cerita 65, masyarakat khususnya responden mengharapkan obat Covid-19 segera ada. Optimisme ini dilihat dari nilai 646. Keenam, video ini dengan nilai 677 rangking dua, dengan aspirasi tertinggi 85 , fakta dan publik 82 .Video digarap dengan gaya komedi unsur tradisi Bali dipandang responden memiliki alur cerita dan estetik yang cukup menarik. Ketujuh, video ini memiliki fakta tertinggi 81, karena video ini memunculkan blusukkan Presiden Jokowi memiliki alur dan estetik yang cukup 68 dan 61 dengan total nilai 648. Kedelapan, video ini menempati ranking tertinggi dengan nilai 701, walaupun faktanya kalah dengan video yang lain. Nilai tinggi video ini disebabkan mengandung pertarungan wacana yang digarap dengan alur cerita, estetik menarik dan gaya musik video kreatif dan inovatif dengan cuplikan data berita yang mendukung musik tersebut. Responden memberikan persepsi indeks tertinggi karena wacana dan estetik yang ditampilkan memiliki opini pribadi tertinggi 74, fakta, aspirasi, alur cerita 73 menandakan digarap dengan baik.

Variabel yang diukur dalam kuisioner ini terdiri dari sebelas indikator terdiri dari: Video pendek ini telah berdasarkan fakta, telah mewakili aspirasi asosiasi, profesi, masyarakat, dan pemerintah, telah berpihak kepada kepentingan public, tidak mengadu domba, ini mengandung opini (pendapat pribadi), menyajikan unsur kekerasan verbal (kata-kata) menyajikan unsur kekerasan non verbal (Bahasa visual), secara berlebihan, mempertentangkan suku, agama, ras, dan antargolongan (SARA), memuat informasi bohong termasuk hoax dan fitnah, memiliki alur cerita yang runut dan menyajikan gambar yang estetik (indah).

\section{SIMPULAN}

Dunia digital informasi membuat pertarungan wacana video pendek tema Covid-19 di media WA semakin 
bersaing. Hal ini menunjukkan aspirasi yang tinggi terkait dengan fenomena corona virus yang menimpa dunia secara global dan khususnya Indonesia. Aspirasi yang tinggi tersebut bersaing memenangkan pertarungan wacana yang mengandung fakta dengan hoax untuk memenangkan pengaruhnya di masyarakat. Video dengan fakta memiliki nilai yang tinggi, namun karena belum digarap dengan alur cerita dan estetik belum menjadi perhatian responden. Pandemi ini memunculkan kreatifitas, inovasi di masyarakat produksi, distribusi dan konsumsi video pendek sampai pada ruang privat di masyarakat. Konsumsi yang bersaing antara fakta dan hoax di WA group dapat memengaruhi pilihan politik dan kepuasan masyarakat. Diperlukan usaha-usaha kreatif berbagai pihak untuk menyampaikan informasi berdasarkan fakta, mewakili aspirasi, berpihak kepentingan politik, tidak mengadu domba, opimi pribadi, sara, hoax dan fitnah, estetik, kekerasan verbal, yang mengandung konten (isi) alur cerita dan alur cerita, estetik serta terhidar dari kekerasan verbal dan visual.

\section{DAFTAR RUJUKAN}

Annistri, Ayunindya, Mohammad Syahriar Sugandi, (2019). Analisis Wacana Kritis Sara Mills dalam Video Klip Musik Despacito Karya Luis Fonsi, Jurnal Dialektika Vol 6 No 1: Program Studi Ilmu Komunikasi, Publisher: Fakultas Komunikasi dan Bisnis Universitas Telkom

Anom A., \& Revias Purwa Kusuma M. (2019). Pengungkapan Estetika Fotografi "Instagramable" Di Era Pariwisata Destinasi Digital. Mudra Jurnal Seni Budaya, 34(3), 319-324. https://doi.org/10.31091/mudra. v34i3.787

Ardianto D., \& Riyanto B. (2020). Film Tari; Sebuah Hibridasi Seni Tari, Teknologi Sinema, dan Media Baru. Mudra Jurnal Seni Budaya, 35(1), 112-116. https:// doi.org/10.31091/mudra.v35i1.856

Aziza Listiana, AdistikahAqmarina, (2020). Pedoman Pencegahan dan Pengendalian Coronavirus Disease, Kementerian Kesehatan RI: Jakarta.

Bardici, Minavere Vera (2012). A Discourse Analysis of the Media Representation of Social Media for Social Change - The Case of Egyptian Revolution and Political Change. Thesis Submitted for Completion of Master of Communication for Development, Malmö University: Sweden

Eriyanto, (2001). Analisis Wacana. LKiS: Yogyakarta.

Ferninaindis N. K., Wirawan I. K., \& Santosa H. (2020). Penerapan Konsep Warna Dingin Pada Tata Artistik Program Televisi Dunia Anak TVRI Bali. Mudra Jurnal Seni Budaya, 35(1), 40-47. https://doi.org/10.31091/ mudra.v35i1.715
Hall, Stuart.(2011), Budaya, Media, Bahasa. Yogyakarta: Jalasutra.

Juditha, Christiany, (2018), To Reduce The Spread of Hoax, Symbolic Interactionism in Anti Hoax Virtual Community, Puslitbang Aplikasi Informatika dan Informasi Komunikasi Publik: Kementerian Komunikasi dan Informatika RI.

Kurnia, Ari. (2017). Fenomena Akun Anonim di Media Sosial Sebagai Sumber Informasi dan ekonomi. Journal Communication Spectrum, Vol. 4 No. 2 Februari t Juli 2017, Program Studi Ilmu Komunikasi Universitas Bakri Moleong, J. Lexy (2017). Metodelogi Penelitian Kualitatif (Edisi Revisi), PT. Remaja Rosdakarya: Bandung.

Pa trut, Bogdan, Monica Pa trut, (2014). Case Studies on the Political Power of Social Media. Vasile Alecsandri University of Bacau: Romania.

Prawitasari, Regina Wikan Pangrepti, (2014). A Critical Discourse Analysis Of Three (3) Advertisement Entitled "Always on,Bebas Itu Nyata" Girl'sVersion. Thesis Study program ofEnglish Department of Languages and Literature, Faculty of Cultural Studies: University Brawijaya

Sarmita, I Made, (2019). Wacana KB Krama Bali: Analisis Persepsi Warganet di Media Sosial FaceBook. Jurnal Kajian Bali (Journal of Bali Studies) Vol 9 No 2 (2019): Dunia Politik dan Hospitaliti Perempuan Bali, Publisher: Pusat Kajian Bali Universitas Udayana.

Setyorini Nurul, (2017). Perempuan dan Kejahatan Cyber: Analisis Wacana Kritis Pemberitaan Perempuan di Media Sosial. Jurnal Studi Kultural: Pendidikan Bahasa dan Sastra Indonesia/ Universitas Muhammadiyah Purworejo.

Walter, Ekaterina, Jesica Gioglo, (2014). How to Use Visuals, Videos, and Social Media to Market Your Brand "The Power Of Visual Storytelling". New York Chicago San Francisco Athens London Madrid Mexico City Milan New Delhi Singapore Sydney Toronto.

Wirawan, I Komang Arba, (2017). Komodifikasi Tubuh Perempuan dalam Kover Majalah Playboy, Pusat Penerbitan LP2MPP: ISIDenpasar. 